\title{
Ecoremediation Educational Polygons in Slovenia as Good Examples of Experiential Learning of Geography
}

\author{
Mojca Kokot Krajnc, Jerneja Križan, Ana Vovk Korže, Nina Globovnik \\ Faculty of Arts, International Centre for Ecoremediations, University of Maribor, Slovenia
}

\begin{abstract}
Teaching in the 21st century is focused on learning for life and sustainable development. Lifelong knowledge, which is focused on education for sustainable development, could only be obtained with experiential learning, where students can come up with new knowledge through research and observation.

Geography can bring many lifelong skills for students. Last years, the teaching of geography made great importance to education on environmental protection in nature itself. Therefore, this paper presents ecoremediation educational polygons in Slovenia. They are intended to offer young people the most authentic environment through direct experience in a real environment and in nature. On the educational polygons in real environments there are conditions for solving problems, while learning and doing research. Education on such polygons offers a great opportunity for young people to acquire practical knowledge, which can be used for effective decisions in life in relation to the environment.
\end{abstract}

\section{Introduction}

Geography is an interdisciplinary discipline which has as its mission to educate the youth about the regional environment, global environment, as well as about the natural and social characteristics of a particular part of the world as the home environment. The essence of geography is to teach students how to orientate in place and to know the knowledge of natural and geographical factors that we need to know in life [12].

Most of the time geography curricula were aimed at teaching about the physical and social characteristics of the global world. With the teaching of geography the physics lecture began to dominate, where students listen and remember only information they have heard and learn about where something is, why it is there and what are the social situation in the region $[1,10]$. In most schools, particularly in eastern and partly in the central part of Europe there is still this learning situation today $[4,8]$. The events that are associated with many natural phenomena, which are caused by man, the teaching of geography in the $21 \mathrm{st}$ century re-focused into a regional teaching. These events brought with them an awareness that is necessary to establish higher quality relationships in land use, mainly to repair relations with the environment and people. Therefore, education of geography in this period also focuses on education for coexistence, multiculturalism and environmental education $[6$, 12].

With such an education is very important to once again put education on the local or the regional environment in the front, which is generally taught through experiential learning. Using experiential learning, students will learn for themselves about the causes and consequences of the environmental management of each individual and we can guarantee that they will develop a responsible attitude towards the environment in which they live. With such an education geography plays an extremely important role $[10,12]$

\section{Experiential learning with geography lessons}

Geography, as we have said, is the science of the Earth's surface and explores the causal and functional links between the phenomena and processes taking place in the environment. Consequently, in geography lessons is highly desirable that the specific processes and phenomena should be learned in the environment itself, as many foreign and Slovenian experts in the field of studying the geography think that the knowledge of geographic space is effectively acquired only by direct observation $[1,8,9]$.

It is therefore necessary to take a big step in the way of teaching geography. Most of geographical knowledge in schools is currently still based on the frontal education, dominated by descriptions and lack of the actual observation of the environment itself. It is therefore necessary to pass from frontal teaching to the research teaching of geography, where the student gets a key role in acquiring knowledge, and teachers take the role of manager, which manages, monitors and directs the education process $[1,7]$. With such an education a central role advocates experiential learning. David Kolb, one of the most important theorists of experiential learning, 
defines concept of experiential learning as "all learning is in direct contact with reality, which teaches ... "[1]. That is very important in geographical teaching. Experiential Learning in the geography can be easily achieved with a lot of fieldwork, which will allow young people a different perspective on the environment and space in which they live. With this method of training, teachers will also have an educational function, as they promote environmental responsibility $[4,6,12]$.

Using experiential learning in teaching geography also enables the achievement of many objectives of teaching geography, for example: narrower and broader understanding of the environment, knowledge of domestic and global world, environmental education.... The objectives that pupils achieved through experiential learning that often takes place in nature or laboratories are clear and pupils permanently acquire them, because they often get to these findings by themselves, because they participate in a real environment, which is the subject of teaching and there is no abstraction or picture of certain phenomena [11].

With geography lessons, experiential learning is best expressed through field work, field trips, laboratory work, science days and practical teaching, where teacher and student work together to meets its objectives. Such learning offers many advantages over other forms of training. The advantages are [6, 12]:

- Originality, as the participants in the educational process are in an authentic contact with the environment, about which they learn;

- Integrity - students are always learning about the whole and they must when teaching one part, also understand and learn the whole picture of the treated area;

- Mix of knowledge through various learning objectives.

\section{Slovenian education system and geography}

Slovenian education system takes place from kindergarten to getting the education at faculty. In Slovenia geography is presented in primary, middle school and college.

\subsection{Slovenian education system}

Formal education in Slovenia is starting in kindergartens, which are public and private, they are not mandatory. Compulsory education begins in elementary school and lasts for nine years. In primary school pupils enter with the age of six and they completed it when they are fourteen. After completion of primary school, young people continue their education in [16]:

- Vocational education, which lasts for three years and after completion they obtain a profession;

- Secondary technical and vocational education, which lasts for four years and ended with a vocational baccalaureate;

- General secondary education and high school education - Gymnasium lasts for four years and ends with a general baccalaureate. In this form of education they cannot get a profession, so it is necessary to continue their education at colleges, which most of them are public and some are private.

Education after fourteen years of age is no longer compulsory and it is the free choice of every individual [16].

\subsection{Geography in Slovenian education system}

Geography is in a college education as a separate teaching and non teaching program. Recently, in the Slovenian education system it is observed that geography is slowly losing its importance, because it is not one of the national subjects [7].

In elementary school, students meet with geography in the first three years by the subject called "Society and the environment". Geographical content is based on the knowledge of the local environment. In sixth grade pupils receive a separate subject called Geography. In sixth grade they learn about the Earth as a whole, in the seventh about the characteristics of Europe and Asia, in the eighth they learn about the characteristics of America and Australia and in the ninth grade about the characteristics of their country Slovenia [3]. Number of hours of geography across the primary school is 221 hours. Moreover, the geographical content is also included in the various elective subjects such as "Human life on Earth", "Exploring the home town" and "Environmental Protection" [3].

In secondary schools there are only 70 hours per year available for geography. Geography is represented in secondary schools as a whole subject only in general and technical gymnasiums, everywhere else is grouped into the subject called "Social studies". In the first year of gymnasium, students learn about the characteristics of general geography, in the second year they learn about the World and in the third year about their home country Slovenia. In fourth year have geography only those, who choose geography as subject for graduation and learn only content for graduation. Also in vocational and technical schools geography is next to history and sociology involved in the subject collectively as "social sciences" and is not present as subject alone $[6,7,8]$.

In the curriculum for geography in primary and secondary education in Slovenia, the mission of 
geography is to bring to the young people to obtain knowledge, skills and abilities, which can be oriented in the modern day and age; it helps to understand the local and wider area and educate them to properly evaluate the environment and respect it. Geographical knowledge includes knowledge about the country Slovenia, the European Union and the world. It also includes knowledge on environmental protection and rational management of it and training for sustainable development, so geography is a necessary part of basic education [2]. Geography lessons train students for responsible, active and several people in relation to other people, for responsible to the natural and social environment. Students can with the acquired knowledge solve spatial problems in the harmony between nature and man $[2,3]$.

These students' competencies in the curriculum of geography led up to restore, as part of geographical teaching and as an integral and compulsory part of the education, field trips and field work. With that there is a wish in the Slovenian education system by the subject geography in particular to strengthen the learning experience, which educate children for future life $[2,3,7]$.

\section{Experiential field work in teaching geography in Slovenia}

The most appropriate way to assure the experiential learning in geography lessons is the field work. Field work is more complex method for studying the geographical environment, because it is didactically and practically very difficult to perform it well. In field work students have the opportunity to easily link theory with practice, learn and recognize the cause-effect relationship between processes and phenomena in the natural and social environment. Learning is clearly and directly. Student is coming to some understanding with simple research methods (observation, orientation, measurement, reporting) by himself. This knowledge can be later used in their lives $[2,3,5]$.

Geography curricula recommended teachers to choose the most active forms and methods of teaching in school. The geography curricula also recommend taking a lot of attention to observation in the physical environment in order to increase the effectiveness of experiential teaching $[2,3]$.

In Slovenia is a major effort underway to make the teaching of geography dominated by experiential learning, which would successfully develop student's geographical and critical thinking. Despite of all efforts, there is still more than $80 \%$ of all teaching geography content in the classroom, which is delivered in the form of frontal teaching [8].

Through a national research about geography education has been shown that teachers know that the field work bring many positive attributes to students and is also required in curricula, but they don't often choose such forms of work. The problem arises already in the organization of the field work. Teachers don't have many experience and even knowledge for organizing the Field work, because on our faculties there was no training for future teachers to organize active forms of field learning. The renovation of the faculty programs for the geography education brings this knowledge back into the education system of future teachers. Teachers have also problems with finding an appropriate location, to ensure the safety of students and big problems with finances, because the field work as a school excursion must have a minimum cost for the students $[7,9,11]$.

These guidelines include complete descriptions of the fonts, spacing, and related information for producing your proceedings manuscripts. Please follow them.

\section{Ecoremediation Educational Polygons in Slovenia}

As before stated, the big problem of experiential learning geography in Slovenia in particular is that teachers have great difficulties in organizing themselves and finding a suitable place for excursions and field work.

Because of such difficulties in Slovenian education and because there is a great emphasis on establishing a problematic geographic content with an emphasis on environmental problems related to specific regional issues in the geography curriculum, the International Centre for ecoremediations from the University of Maribor with its partners and Ministry of Education and Sports, decided to start the project called "Establishment of the implementing conditions for experiential education for sustainable development". To take account of the environment in all activities in the area of education, we have only a great opportunity to offer young people the skills to be able to properly decide in life. Education on the polygons is oriented in "learning by doing", or socalled experiential education, because only with this type of learning, a long-term effectiveness of education and education of young people on the basis of awareness of the active role of the individual and society in the modern world, can be achieved. This will not be achieved by learning in the classroom, but direct experience in the field is needed and also a direct contact with nature and ecosystem technologies. The purpose of such education is that each individual is faced with certain problems and they start to think about them, also they are looking for the most appropriate solutions. With this type of education young people can decide, with help of direct experiences, in favor of nature and environment and with their knowledge and 
decisions they can make significant contributions to sustainable development in their local environments.

For integrated solutions to environmental problems in the environment, have recently proved their value solutions, called ecoremediations, they contribute to achieving the sustainability of local areas. Ecoremediations are methods by which we solve, with the help of nature, degradation problems and with that, we prevent further pollution, preserve and improve the environmental situation [13]. From this perspective all polygons were named ecoremediational, because students learn, how they can solve a variety of environmental problems with a use of natural methods and how they can protect the environment from pollution. Ecoremediations are those technologies, which require the knowledge of natural environmental factors [13], because only with the knowledge of these, can be properly determined, what is the right decision in protecting the environment and preventing environmental problems.

Ecoremediation polygon is intended for different age groups. On the polygon there are able to learn children from kindergarten, primary schools and secondary schools. Also, on polygon future teachers of geography and geography students educate. On polygon students can learn about the environment as ecosystem units, and through education in an environment, they can aware of the consequences of their actions and interventions.

Ecoremediations are in the Slovenian education system something innovative and they bring a lot of help for raising awareness of the environment. Presented is innovative view to solve many environmental problems such as improper management of the running and standing water, wastewater, soil erosion, water pollution, soil and air.

\subsection{Ecoremediation Polygon of Modraže}

A polygon is located in a small village Modraže in the municipality Poljčane in the middle of the natural landscape. The center of the polygon is a learning center that is intended for stay and live there as well as to do various teaching experiments. Facilities for accommodation are made so that students can stay longer in this natural environment and live in harmony with nature. Access to the polygon is very easy, because past Poljčane is passing the railroad. From the railway station Poljčane to the polygon is organized transport. It is also possible to get to the polygon by car or bus, because the path is marked with special signs. Polygon is managed by the International Centre for
Ecoremediation together with partners and the Municipality of Poljčane, which is very obedient and wants for his community a number of similar projects, which have already started.

Natural characteristics of the polygon are very varied, as an interweaving of different landforms, the area is very rich in water with standing water and a liquid water. Because of such diversity, there is also a large plant and animal diversity as the polygon itself has some protected animal and plant species. Polygon environment is appropriate for the sensory and emotional experience of the nature and a suitable place for experimental teaching of physical factors in the geography [14].

Educational facilities enable independent or guided learning and teaching of the laws and processes that occur in nature (ecosystems), as a basis for understanding complex physical geographical processes in the environment.

On the polygon natural and anthropogenic ecosystems created can be found (see Figure 1), which act as a connected ecosystem. There can be examined: mixed deciduous forest, coniferous forest, forest edge, isolated springs, streams, river embankment and its vegetation buffer zone, dry meadow, wet meadow - wetland, anthropogenic farm, pond and fish pond. These ecosystems are already available for study. Set in wetland, multiple fitoremediational area, compost, buffer zones, such as regulated rivers and unregulated rivers, green roof, etc. [14].

The largest natural ecosystem on the polygon is a forest in which different types of forests can be found. It consists of mixed deciduous forest and coniferous forest. In the woods the tree line between the leaf and mixed coniferous forest can be actually watched [14].

In the area of a polygon around the valley runs a small stream, which is located in its natural channel and had no interference and was not regulated. Water in stream is clean, it runs through a sparsely populated area. In the single stream pools, rapids and gravel beds can be seen. A special feature of the stream is two protected species. These are Austropotamobius torrentium and Cordulegaster heros. By the stream the shoreline of the stream and shrub hedges are preserved. Vegetation along the stream and with shrub vegetation presents a haven and habitat for many animals. It has a soothing function of the immediate environment, reducing wind and mitigates the effects of drought. It also keeps the flooding and clean water [14]. 

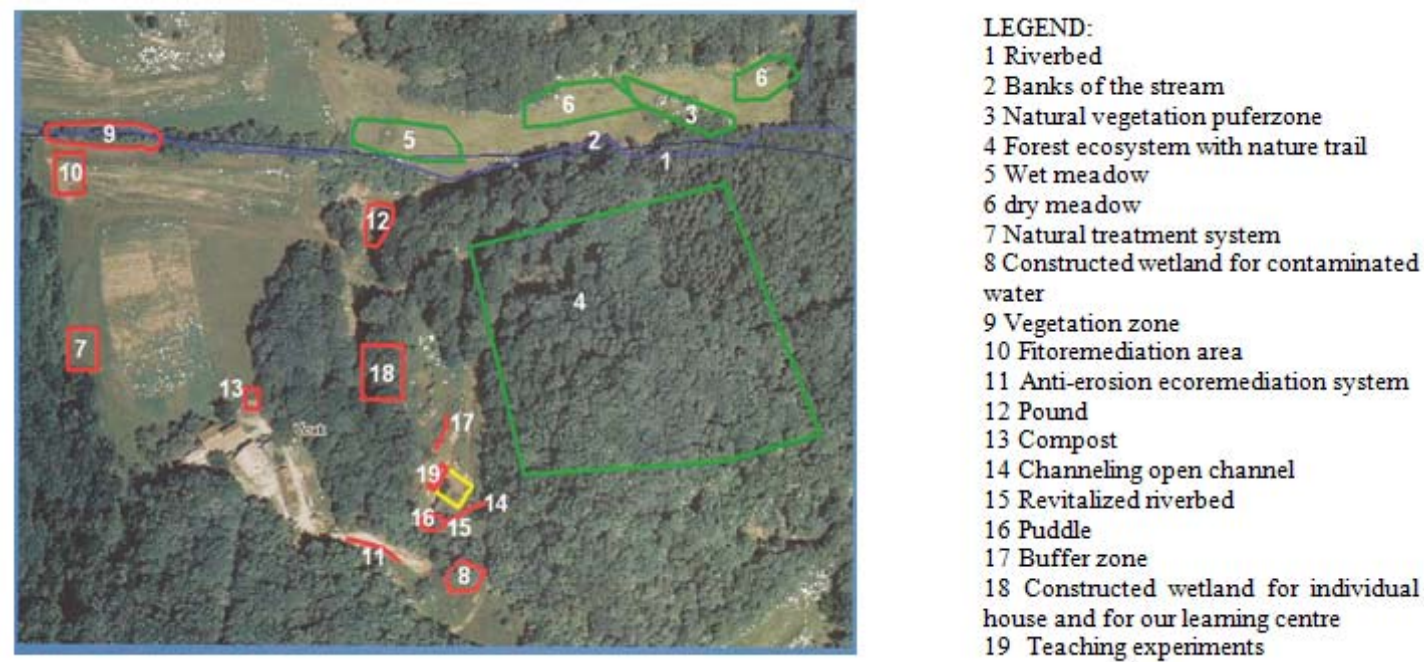

Figure 1. Legend of Ecoremediation polygon

On the ground, there is a water ecosystem posed by Marsh meadow along a stream, as well as drought lawn. Wet grassland is of great importance, since the typical marsh vegetation and soaked the soil present a high biodiversity of the very ecosystem [14].

This site gives up great opportunities for experiential learning in physical geography. On the polygon is a large range of different field equipment. With these can students acquire a variety of different physical geographic data. The work on the field is oriented in a team study and research, where students get their knowledge in a group. The students learn also to work as a team, which is very useful for life, because not everyone knows everything. All tasks on the polygon are designed to require students to think about environmental problems, which are detected and observed in the learning environment. With the acquired knowledge on the polygon, students may indicate solutions to these problems and they can transmit this knowledge to their home environment. On the ground it is possible:

- To acquire knowledge and skills in climatogeography. In the context of a polygon weather house can be established, in which the weather is observed. At the site you can measure a temperature wind speed as well as air pressure. By observing the weather the microclimate of a given area can be determined.

- Acquisition of knowledge and skills in the areas of geomorphology: The students can walk alone to get a general feeling of relief and its characteristics. By collecting rocks in the area students can train in the study of types of rocks as well as the determination of chemical properties of soil and on the basis of findings determine how stone building area is there. Students can also observe and sketch a set of the landforms that occur on the ground. Polygon also offers more than just identification of the forms of relief; it also learns students about the causes and effects of erosion on the type of terrain and type of erosion activity.

- Acquisition of knowledge and skills in the areas of hydrology: Students on the polygon get basic knowledge, what are the characteristics of standing and running water. They can be trained in determining the physical and chemical analysis of standing and flowing water, as well as in interpreting the data alone. There is also a possibility to construct simple devices for monitoring characteristics of water.

- Acquisition of knowledge and skills in the field phytogeography and zoogeography: Through observation students can determine by themselves the dominant plant and animal species in this area. They have a possibility to compare natural vegetation with anthropogenic vegetation and to identify the interactions and consequences.

- Acquisition of knowledge and skills in the field pedogeography: At the site students learn and practice the various methods of identifying characteristics of the soil. Through various drills they learn how to take a soil sample and analyze soil properties. In the excavated soil pit train they train in the identification of soil horizons. With feeling they learn to determine soil properties such as soil structure, stability of structural aggregates of soil permeability to water, the reaction, the smell of soil and soil color. The opportunity is given to them to train in determining the chemical properties of soil by using chemical reagents.

- On the ground, there are also placed three objects: compost, storm simulations and simulation of the permeability of surface, with which students can learn in the wild what storms represent in the environment, how much water is a potential self-absorbed and how much dry soil 
is already soaked and on the basis of these findings they can conclude the formation of avalanches [5]. With help of simulations of the permeability surface students can identify how important it is to have the possibility of rain water runoff into the subsoil. With compost they learn how to produce homemade humus and how to produce humus.

- Particular attention is given to the constructed wetland, which was built for educational purposes, as well as our simulation model. With the help of wetland, students can learn about the power of nature to clean wastewater. Constructed wetlands consists of 3-4 each successive shafts, which are insulated with foil and filled with medium through which the water horizontalvertical flows under-surface. With the participation of micro-organisms and marsh plants, water is purified to the required standards, so is drained clean back to the environment. Students can on an actual case determine, with chemical analysis, level of water pollutants before the treatment plant and the quality of water through the outlet of the wetland. Model of plant equipment serves for direct observation of what happens to the contaminated water. Here is usually, water colored with organic dyes, poured into the model and we can observe what happens to the water in the model and what water comes from the model.

\subsection{Ecoremediation polygon on standing water in Sveta Trojica}

Ecoremediation polygon on standing water is located at the lake in the village Sveta Trojica V Slovenskih goricah and its origin is anthropogenic. The lake was created by damming of the stream Velka. The lake is $1260 \mathrm{~m}$ long and $280 \mathrm{~m}$ wide. With its 44ha area and $5.5 \mathrm{~m}$ depth is intended for aquaculture and fisheries. Due to its size and favorable location, the lake is also used for tourism activities, especially boating and walking around the lake.

Polygon was established in order for students to come up with experiential education to new knowledge of how to deal with standing water and what is their significance in the environment. The lakes are important water reservoirs, habitats for many animal and plant species, they are mitigating the effects of climate change, they are sources of food, in short, they have a great ecological and economic importance [13].

Trojica Lake as anthropogenic lake, its ecosystem is sensitive, because the process of eutrophication (the enrichment of water with inorganic and organic substances) in artificial lakes is significantly faster than in natural lakes, where there are different hydromorphological conditions and bio-chemical processes. On the genesis of lakes from oligotrophic to eutrophic affect mainly anthropogenic factors - a man whose activities mainly add phosphates and nitrates.

Indirect impact on the eutrophication of lakes has also hydrological state of the groundwater and inflows. The reduced throughput leads to poor circulation of water and oxygen in the lake, which represents a qualitative change and reduces the biodiversity. This chain reaction leads to increased productivity as a result of increasing nutrients. All this once again, produces a range of processes such as: an increasing number of dead materials at the bottom, reducing water depth and thus higher temperatures and increased activity of aerobic bacteria. In aerobic conditions, the sediment starts to release phosphorus, which is one of the main contaminants. The main sources of direct pollution of the Trojica Lake are waste waters form village. No direct pollution of the lake is coming from storm water from roads and agricultural land. The big problem of such pollution is that location is close to the highway and there are extensive areas with intensive agricultural production.

Despite lake is anthropogenic, it has an outstanding biodiversity. Due to integration of water and maintained forest ecosystem, this area has an outstanding importance for natural conservation, especially for a group of amphibians, since they have available suitable aquatic and terrestrial habitats. Until now, eleven species of which five are on the list of protected species were found here. The area around the lake recorded 24 species of butterflies. The areas surrounding the lake very important for the bugs, since there are about 300 known species, many of them are known to live only in this habitat in Slovenia.

Biodiversity is particularly high especially on the north side, where there is a wetland, natural pond, buffer zone, vegetation zones, land reclamation ditches. This is the perfect environment for experiential learning, where students gain knowledge about organic and natural meaning of these protective elements of the lakes (see Figure 2):

By observing the students learn about wetlands, that this is essentially a natural water retention basin. The water level varies throughout the year as also when there is heavy rain. Wetlands are dynamic ecosystems, which absorb large amounts of water in rainfall and then emit it slowly into the environment that is why they are an important source of water during summer droughts. Thus, the wetlands in this part are the water reservoirs that absorb water and they deliver the water into the soil. They have a beneficial impact on the environment, because wetlands are often covered with lowland forests, which by itself mitigate flood peaks and $t$ collect water from lake and it is transmitted through 
transpiration into the atmosphere. Wetlands have in this part of the lake an important role in flood safety.

On established phytoremediational perches will students get knowledge about the importance of plants that have the ability to clean water or soil. Phytoremediational perches are at the lake in place to prevent runoff of contaminated water into the lake from agricultural land. Perches are planted with different types of plants that have the ability to address the problems associated with contamination of soil due to excessive use of fertilizers and nitrogen compounds and running of that into the lake water. The students will recognize these plants here and will learn about their characteristics.

A pond, where students will learn with observation, physical measurements of air and water and chemical measurements of water, about the properties and characteristics of standing waters and their beneficial effects on the environment. Production ponds are extremely active, as they provide a variety of aquatic environments and species diversity in general. Ecological importance of ponds is reflected in the improvement of ecological conditions, maintenance and cleaning water, increasing biodiversity and improving the microclimate. The stability of an ecosystem in a pond contributes significantly its and riparian vegetation, which provides numerous ecological niches relevant to the existence of many species. The chemical measurements of water that students will assessed are going to give an answer if standing water, which are covered with various plants that grow where there is a lot of moisture in the soil, have a better water quality than those waters dominated by only one type of plant. For the comparison, they can take a water sample from the lake because the lake in most of the southern part has vegetation and some parts are without vegetation.

In the northern part of the lake is established a natural buffer zone, which represents the area between the land and aquatic ecosystems. In fact, this is the buffer zone, which reduces the negative impacts of catchment areas on the lake ecosystem. Grass, shrubs and trees improve conditions for sedimentation of suspended particles; take up nutrients and protect riverbanks from erosion. This natural element is a good education element, where students can evaluate with observation the role of vegetation belt of lake water against pollution and learn about all its features.

In the northern part of the lake is preserved with many natural ecoremediation elements for securing and protecting the lake. They are naturally created and maintained systems. They provide excellent conditions for experiential education on the importance of riparian lake elements which help to preserve biodiversity of lakes and quality of the water in the lake.

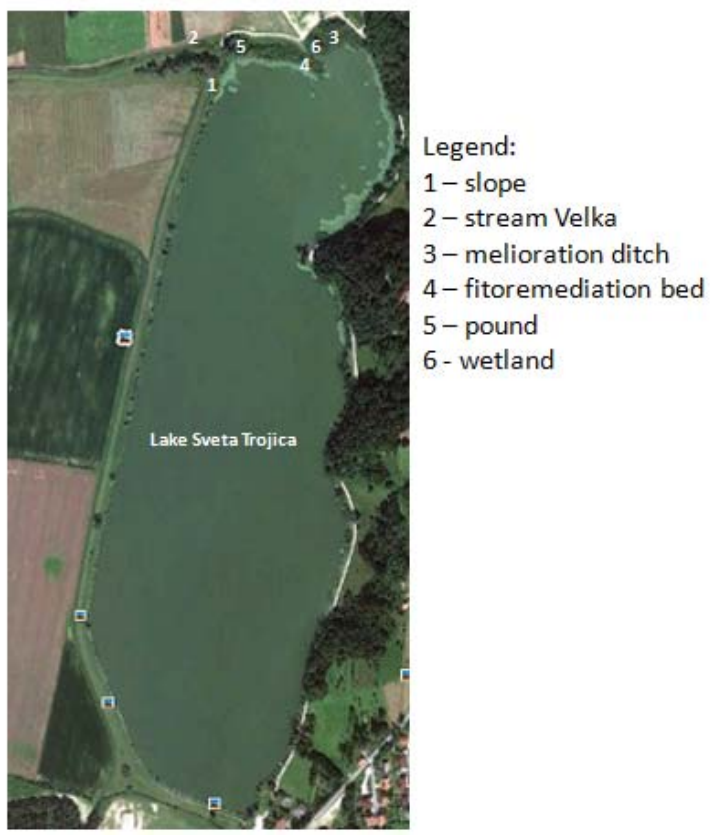

Figure 2. Legend of Ecoremediation polygon on standing water in Sveta Trojica

Students will be able to monitor the physical and chemical changes within the system of standing waters itself and can further cooperate in setting up new systems and observation places. They can also help in maintaining systems and with that they can learn about processes in standing waters.

\subsection{Educational Polygon Zone Tezno}

Zone Tezno is an old industrial area of the city of Maribor, which was previously focused on the automotive industry. Today in the area revitalization is taking place, with which the Zone Tezno receives new look. The area continues to be an industriallooking, but in the old industrial buildings companies that produce products with high technology and various service activities that meet the needs of people, are moving. The area spreads over 108 hectares, of which 48 hectares is vacant and inside built-up areas is about 8 acres of green space, which is intended primarily for landscape appearance, as well as the relexation of people and conservation of biotopes of various plant and animal species.

Part of the area is intended for educational activities, where students can learn about the characteristics or features of urban ecosystems located in old industrial areas. For urban areas, which are also part of the old industrial area, is characterized, that a high proportion of built-up areas is built-up with impervious surfaces. Also, these are areas where the so called heat islands are dominant, where the temperature is higher due to heat emission from buildings, than in the area. All of these will students 
gain knowledge in the field through experiential learning.

With the physical measurements of temperature students will assessed, what is the air temperature in a completely built-up areas with impervious surfaces and what is the temperature of the air in built-up areas with green space, which have the possibility of leakage of water into the depth and they allow phytotranspiration. The students will also observe with measuring of soil moisture, what is the relevance of impermeable surfaces for ground water.

In the zone there have been for the educational purposes established some ecoremediation learning models: the rain garden, green walls and vegetation belts. On the basis of these learning models students learn about the benefits of green infrastructure in ensuring the quality of the environment, the creation of new habitats and suitable working environment for local employees. Rain gardens are located mainly in order to clean waste water flowing from roofs and parking lots. Students use this model to obtain through observation and chemical analysis of rainwater, knowledge such as how the is the rain water contaminated and what is the role of rain gardens with cleaning the rainwater.

Area also aims to generate energy from renewable energy sources. In the zone there is a solar power placed. Thus students can learn from near how the solar power works and in concrete terms, they can gain knowledge of what all is needed for solar power and how to handle the production of electricity.

Area Tezno is a good view of the educational polygon on the urban environment, in particular about what can be achieved by the use of renewable energy and sustainable development of green infrastructure area, which is based on the circuit of all substances, as is typical of natural ecosystems.

\subsection{Permacultural Polygon Dole}

Permacultural polygon Dole is located in the village of Dole. It was set up in order to solve the problem of producing self supplies in Slovenia. Currently, Slovenia produces less than half of their own food, we import the rest. Based on data from the European statistical office Eurostat, Slovenia is by the extent of arable agricultural land in the 24th place among EU member states [17], which is due to inappropriate use of land. Daily about 11 hectares of land is used for construction, of which 7 hectares of agricultural land [18]. Unfortunately, only a small proportion of arable land is planted by organic standards, which provide healthy food, sustainable management and independency.

The aim of the polygon is to show students options for self supplies in the traditional and innovative manner. On the site students receive knowledge from different permaculture and natural way of life where people can take much advantage with regard to natural laws. This entire works on the principle of permaculture, which tends to that every element in the system, performs as many functions and that as many elements are supported between themselves. On the site there is a system for food self-sufficiency and system for allocating things in the environment that will minimize energy consumption while maximizing needs.

Students will be experiencing with their senses and learn about the interconnectedness of many functions. In this direction the whole concept of a polygon is created. The center of the polygon is a yurt, which represents the traditional residence of the old Mongolian nomadic tribes, and is usable in all seasons, as it stands at the center of the solar trap. Solar trap, which is set before a yurt, is creating a warmer microclimate, which comes in handy especially in the colder part of the year. Solar trap is composed of bushes, small trees, up to large trees and is facing south, it protects environment and with that it creates a warmer place before a yurt, that is why is so beneficial to stay. It is also important in terms of energy consumption, because it uses less energy in residence. In parallel with a yurt is placed water feature, which has - like everything in permaculture - more features. This water element acts as a mirror in the colder part; thereby it contributes additional passive solar housing. In summer the water element has a beneficial effect, because daytime evaporation cools the surrounding area and at night it warms because of higher temperatures. Water element also contributes to the biodiversity of an area. The last part that is added is a greenhouse, also there is a small kitchenette and toilet facilities, and it serves for education of planting, which are always there.

On the polygon the students acquire knowledge in the field of permacultural farming. Each year, students take care of some of their perches as shown in the picture below. This year, students farmed on the polygon by the principle of vegetable effect of three sisters. American Indians have used beans, corn and squash to grow together in groups. Three sisters, as they say, assist as follows: corn provides support for climbing beans, beans provide the nitrogen needed by corn and pumpkins, pumpkin grow over soil. Corn and pumpkins are quite demanding in nutrients, so it is not usually to grow corn for a number of years in the same place. Thus, it is not the problem. The space is efficiently used, a weed has no place, soil is watered, if necessary - but not much, all three sisters are satisfied together.

On permacultural polygon, students learn about different peer connections and found that the permacultural system, things as somehow are trying to round up as much of these things combine in a robust sustainability scheme. All in order, that we can truly live sustainably and do not consume too many resources, because all of this is due to our 
descendants, our children, our great-grandchildren, which could be said at this moment, that we really loose resources, because we are consuming too much.

\section{Importance of Ecoremediations Polygons for experimental learning}

The key aim of Ecoremediation polygon is that students within the Ecoremediation polygon in the individual learning points identify the key environmental problems in the area through the collection of different measurements, analysis, data processing, performance comparisons, etc.. On that basis, the individual student and / or with the help of a teacher, as a catalyst in the learning process, reveals the causes and consequences of environmental problems by himself and on the basis of the collected data looks for solutions to solve it. Student can only after passing through the conflict find a possible solution, and win some knowledge, with that he learns to evaluate and defend, which is a key skill and ability for the future of the student, who will be faced in his formal and informal learning with a situation in which he will have to take different decisions [13].

The concept of Ecoremediation polygon also permits the development of three key dimensions of students' competence, namely: cognitive - acquiring quality knowledge gained through understanding the processes and phenomena and the use of these skills in different situations, in solving various problems; emotional - when the student by learning about and solving environmental problems is also developing a positive relationship with nature - what is good and what is bad for our nature and the environment; and action - to stimulate students to change internalized knowledge and values into concrete actions that you can as an individual contribute to environmental protection.

\section{Conclusion}

With educational polygons, Slovenia got one set of classrooms in nature, where students can get direct experience with the most common environmental problems in Slovenia and they can receive practical and useful skills for life. With creation of this polygon we want in the first place to enhance experiential education and also promote to people the responsibility for nature and for environment. Ecoremediation education polygons are interdisciplinary-oriented and innovative, where students can with all their senses the nature and with a variety of research methods they can come to new findings in the field of physical geography. The acquired knowledge will allow them to be able to act responsibly in the fate of the environment.

\section{References}

[1] G. Butt, M. Hemmer, A. Hernando, L. Houtsonen, Geography in Europe, Geographical Education in a Changing World Past Experience, Current Trends and Future Challenges, Springer, 2006, pp. $93-107$.

[2] Geography curriculum for high school - gymnasium, 2008. (in Slovene)

[3] Geography curriculum for Elementary School, 2003. (in Slovene)

[4] H. Haubrich, Changing Philosophies in Geographical Education from the 1970s to 2005 an international perspective, Geographical Education in a Changing World Past Experience, Current Trends and Future Challenges, Springer, 2006, pp. $39-55$.

[5] D. Holmes, D. Farbrother, A-Z Advancing Geography: Fieldwork. Royal Geographical Association. London, 2000.

[6] K. Kolenc Kolnik, Development of Geographical Curricula and Educational Potential of Geography in the beginning of 21st Century, Dela, Faculty of Arts Ljubljana, 2008, pp. 77 - 87. (in Slovene)

[7] J. Kunaver, School Geography in Slovenia on the break of Millennium, Dela, Facilty of Arts, 2001, pp. 77 - 93. (in slovene)

[8] J. Kunaver, Geography Curriculum content Evaluation with special Reference to the standards of Knowledge and Planning and Implementation of Educational work, http://www.mss.gov.si/fileadmin/mss.gov.si/pageuploads/p odrocje/razvoj_solstva/evalvacija/2000_II/Kunaver_Jurij.p df, in Slovene. Access date: 2 December, 2010).

[9] I. Lipovšek, Descriptive, Explanative or Investigative Geography in School, Zbornik trajnostni regionalni razvoj ob reki Muri, Murska Sobota, 2009, pp. $482-490$.

[10] J.P. Stoltman, Turning points in Geographic Education, Geographical Education in a Changing World Past Experience, Current Trends and Future Challenges, Springer, 2006, $23-39$.

[11] T. Tal, O. Morag, Reflective Practice as a Means for Preparing to Teach Outdoors in an Ecological Garden, Teacher Education, Springer Science, 2009, pp. $242-265$.

[12] D. Tilbury, D. Wortman, Geography and Sustainability the future of School Geography?, Geographical Education in a Changing World Past Experience, Current Trends and Future Challenges, Springer, 2006, pp. $195-213$.

[13] A. Vovk Korže, D. Vrhovšek, Ecorememdiaton for effective protection of the environment, faculty of Arts of Maribor, 2009. 
[14] D. Vrhovšek, M. Vrhovšek, M. Zupančič Justin,..., Education Polygon of Ecoremediation in Modraže, Poljčane, 2009. (in Slovene).

[15] D. Vrhovšek, A. Vovk Korže, Ecoremediation, Faculty of Arts Maribor, 2007.

[16] Slovenian Education System, http://www.eurydice.si/images/stories/slovenski_izobrazev alni_sistem/National_System_Overview-July2010.pdf. Access date: 6 December, 2010.

[17] Crop and animal supply balance sheets for the calendar year, Slovenia, 2000-2010 - provisional data, http://www.stat.si/eng/novica_prikazi.aspx?id=3974.

Access date: 15 June, 2011.

[18] Earth - our wealth and the burden, http://www.forum21.si/pdfFiles/napovednik-13-38.pdf. Access date: 22. April 2010. 